\title{
INSECTS
}

\section{GRASSHOPPERS IN COYOTE SCATS}

THIJS KUIKEN, Department of Virology, Erasmus Medical Centre, P.O. Box 1738, 3000 DR Rotterdam, The Netherlands, ANNA LEIGHTON, 328 Saskatchewan Crescent West, Saskatoon, SK S7M 0A4 and DAN JOHNSON, Lethbridge Research Centre, and University of Lethbridge, Lethbridge, AB T1K 3M4, dan.johnson@uleth.ca

Grasshoppers were unusually abundant in the Prairie Provinces in the late summer of 2001 and 2002. In the Saskatoon area, the most common species found in August 2002 was the two-striped grasshopper (Melanoplus bivittatus) (Fig. 1), and, over much of the area, grasshopper surveys indicated that densities ranged from 13 to 24 per $\mathrm{m}^{2}$ (Scott Hartley, pers. comm., 26 November 2002).

On 8 September 2002, the first and second authors, TK and AL, visited Crawford Lake, which lies $30 \mathrm{~km}$ ESE of Saskatoon, and encountered many grasshoppers, mostly two-striped, on the vegetated low areas at the east end of the lake. Grasshoppers were particularly abundant in patches of sow thistle (Sonchus species), some of which were eaten down to bare stalks. We later estimated that there were

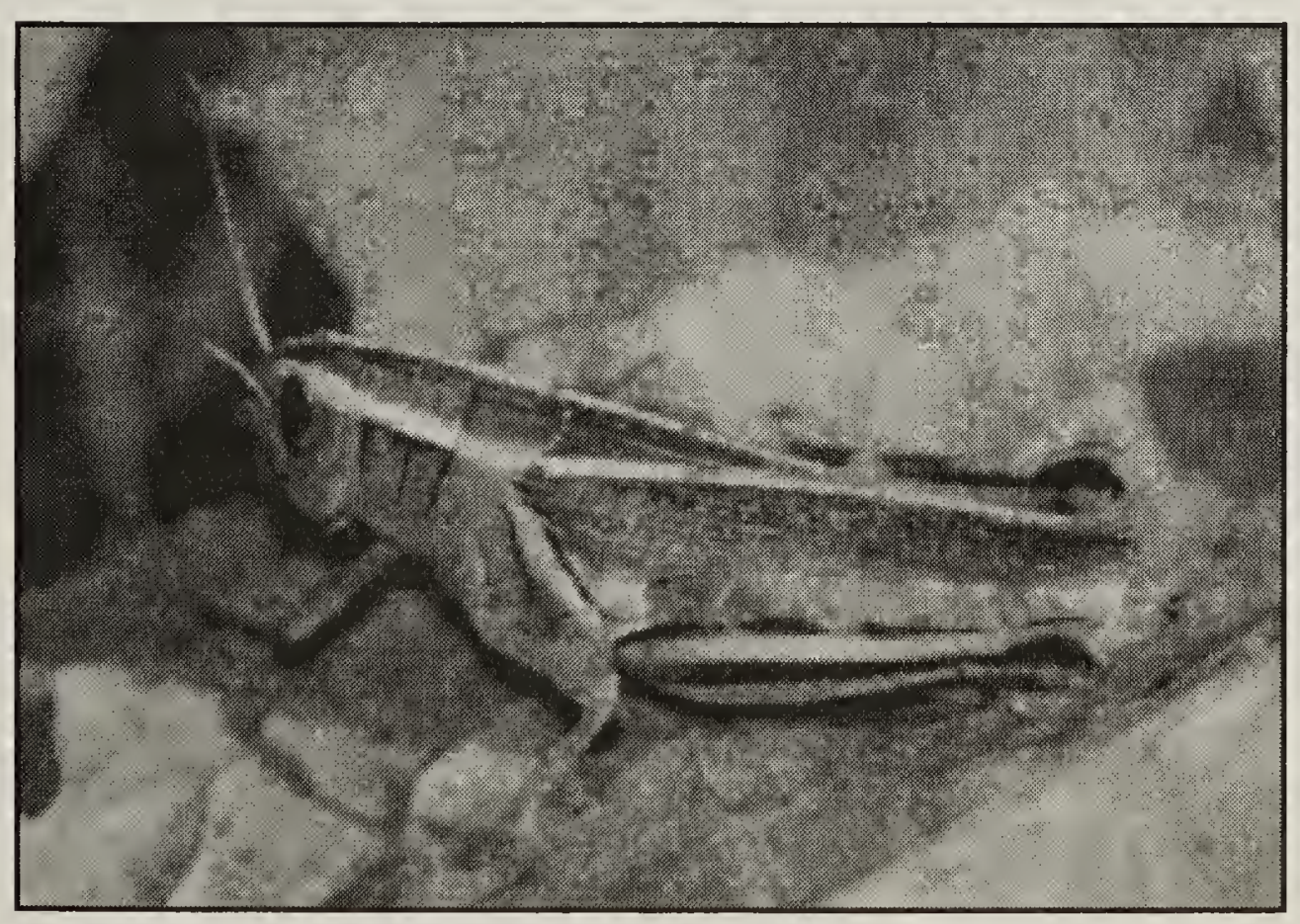

Figure 1. Two-striped grasshopper (adult female)
Dan Johnson

10 to 15 grasshoppers per $\mathrm{m}^{2}$. Grasshoppers netted in the sow thistle patches a week later were identified as two-striped, Packard's (Melanoplus packardii), redlegged (Melanoplus femurrubrum) and lesser migratory (Melanoplus sanguinipes) grasshoppers.

Along a game trail across the mud flats at Crawford Lake, eight intact Coyote scats were found that, when broken apart, appeared to consist primarily of grasshopper remains (Fig. 2). Dissecting one of these scats later (Fig. 3), we found that it consisted solely of grasshopper remains, many of which were large enough to identify. The remains belonged to adult male and female two-striped grasshoppers, with evidence of one red-legged grasshopper and one lesser migratory grasshopper. The 33 whole heads and 2 half heads indicated that

at least 34 grasshoppers were present in the scat. Other grasshopper parts recognized were the drum-stick shaped femur segments with knee joint (41), femur segments (38), hind leg tibia segments (63), other legs (84), wings (84) and broken body segments (63). (Figure 4).

Four days later, another 18 Coyote scats, consisting primarily of grasshopper parts, were found by AL and 


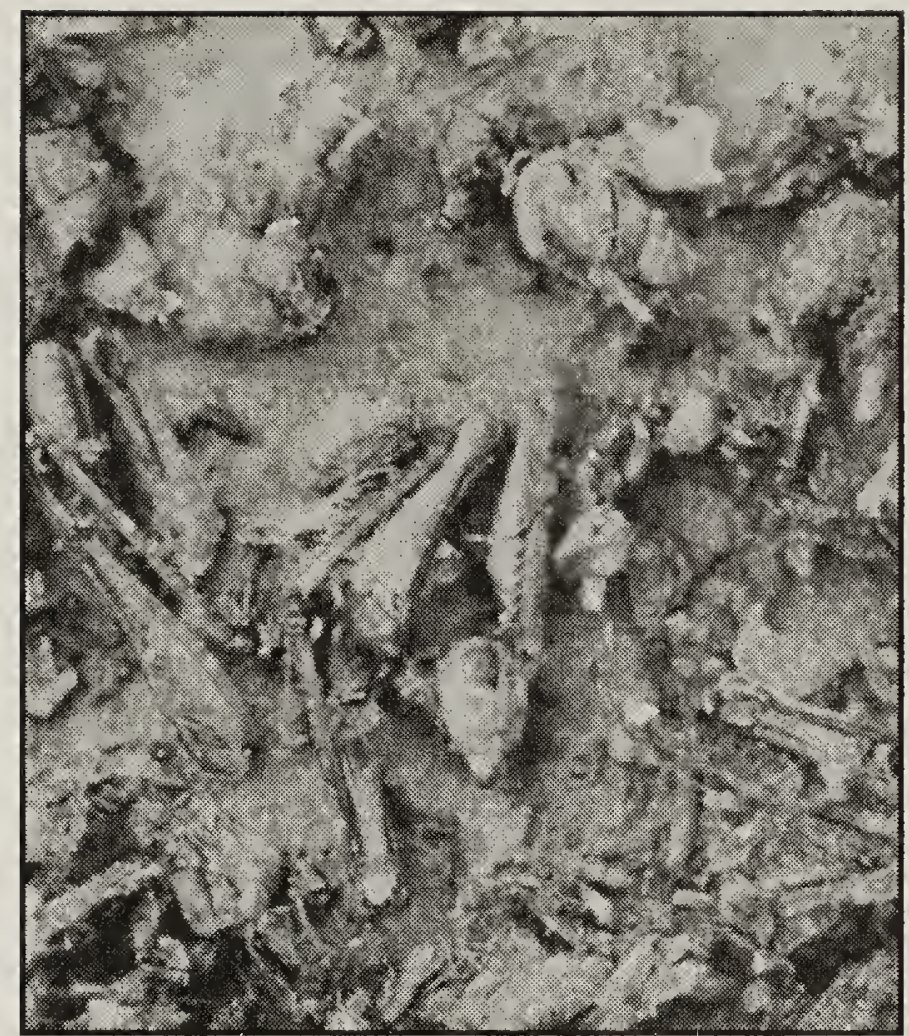

Figure 2. Grasshopper parts in coyote scat broken apart at Crawford Lake on September $8,2002$.

Anna Leighton

Bonnie Lawrence along a $300 \mathrm{~m}$ stretch of mud flats bordering a saline slough $8 \mathrm{~km}$ west of Crawford Lake. At this location, there were an additional 10 scats with some grasshopper remains: one contained a mixture of grasshopper parts and chokecherry pits, five contained some grasshopper remains and four, a trace of grasshoppers. The age of these scats is unknown, but all were intact and lacked mineral crystals on the surface, suggesting that they had been deposited relatively recently.

In summer 2002, grasshoppers were common constituents of Coyote scats found by the third author, DJ, in southern Alberta where grasshopper numbers were similar to those observed in the Saskatoon area. ${ }^{2,10,11}$ Scats examined by DJ south and east of Lethbridge contained remains of mainly two-striped grasshoppers, with smaller numbers of Packard's grasshopper. Two scats observed near Aetna, (July 2529, and August 4), contained mainly twostriped remains, but included small numbers of the clear-winged grasshopper (Camnula pellucida) which was common between Cardston and the U.S. border. Several scats observed near Raymond contained only the two-striped grasshopper. On native and semi-native grassland near the Milk River in southern Alberta, Coyotes apparently utilized some of the other grasshopper species that increased in abundance in 2001$2002 .{ }^{10}$ Observations by DJ, who broke open Coyote scats at the Milk River sites and identified the remains in the field, indicated that the diet included the bigheaded grasshopper (Aulocara elliotti), and white whiskers grasshopper (Ageneotettix deorum), with very few two-striped grasshoppers.

These year 2002 observations suggest that Coyotes feed on grasshopper species with medium to large individuals that do not fly readily. The two-striped is a prime example. ${ }^{6}$ The big-headed and white whiskers grasshoppers are smaller than the two-striped but also spend most of their time on the vegetation or ground. ${ }^{7}$ In contrast, the Carolina grasshopper (Dissosteira carolina), which flies readily for relatively long distances ${ }^{5}$ and was common in the Milk River region in 2002, was generally not found in Coyote scats that year (DJ, unpublished observation).

This same trend seems to hold true for grasshoppers captured by Coyotes in spring. The red-shanked grasshopper (Xanthippus corallipes latefasciatus) was common in Coyote scats collected by DJ and field assistants C. Andrews, D. Drader, D. Watson and S. Van Wilgenburg, during field studies in Alberta in 1992-95 and 2000-2002. It occurs in April as a fifth instar nymph, and is lethargic and easy to capture during morning or evening hours in May and June. This species is the largest grasshopper on the Canadian Prairies (although the Carolina grasshopper has a greater wingspan). ${ }^{5}$ Female red-shanked grasshoppers collected and weighed in 2002 had a mean dry weight of $0.57 \mathrm{~g}(\mathrm{n}=10)$, and 5 th instars, $0.248 \mathrm{~g}(\mathrm{n}=10)$. Smaller spring species, such as the club-horned grasshopper (Aeropedellus clavatus) and 


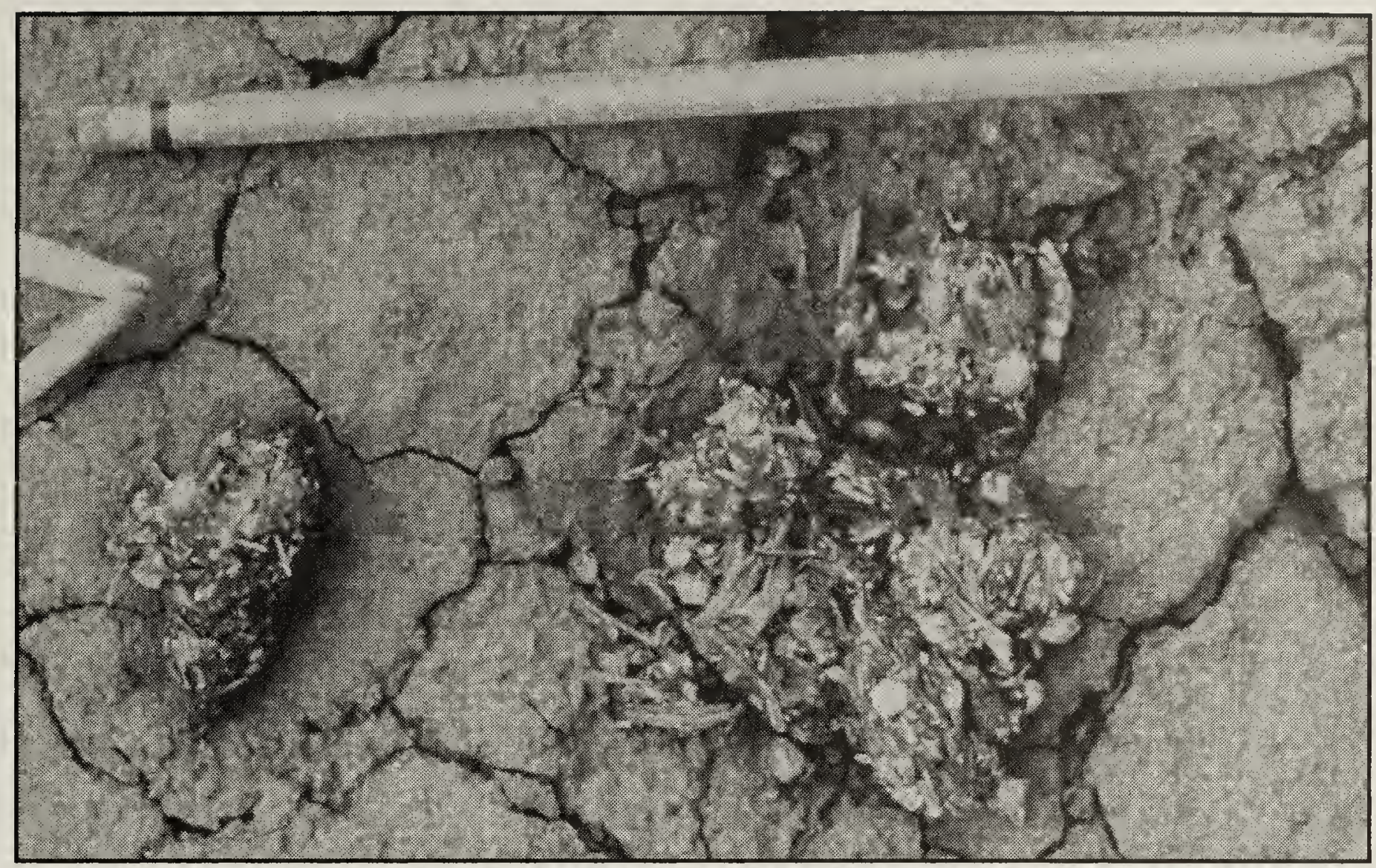

Figure 3. Coyote scat collected for dissection (pencil $=18.5 \mathrm{~cm}$ )

Anna Leighton

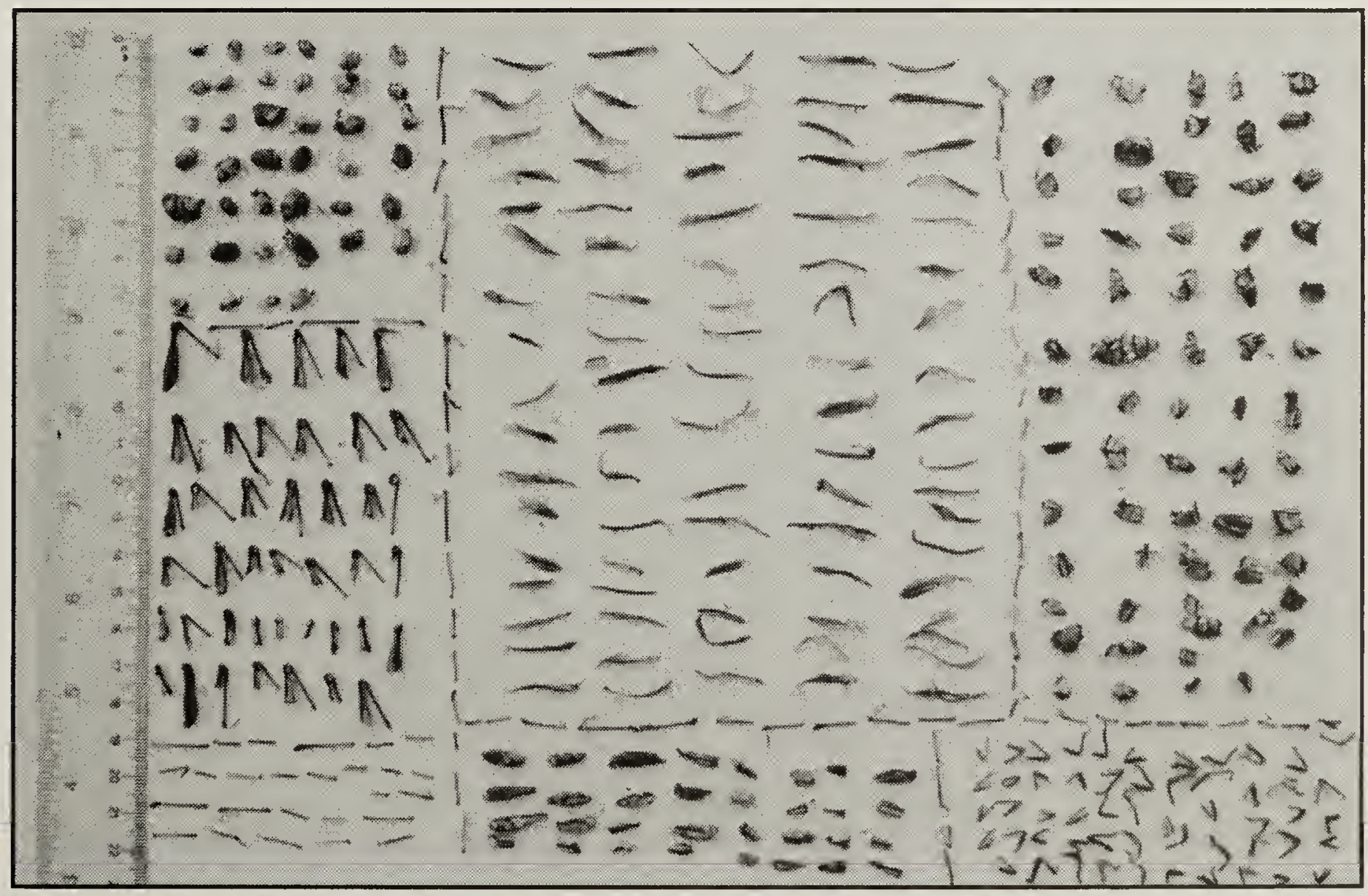

Figure 4. Grasshopper body parts found in the scat shown in Figure 3.

Clockwise from top left : heads, wings, body segments, front and middle legs, parts of hind femurs, hind leg tibia segments and femurs with knee (tibio-femoral) joint attached. Thijs Kuiken

the brown-spotted range grasshopper (Psoloessa delicatula), have not been noted as common constituents of scats (DJ, unpublished observation).
Grasshopper density also appears to be an important factor influencing which species coyotes capture. Lesser migratory grasshoppers have been noted by DJ in 
Coyote scats collected in the past in late summer in southern Alberta, but not in 2002, when the populations of this species were at very low levels (in most cases less than $1 \%$ of the grasshopper community in southern and east-central Alberta, and usually 1 to $10 \%$ in southern Saskatchewan, in 2002) (DJ, unpublished data based on August 2002 collections). Although the three-banded grasshopper (Hadrotettix trifasciatus $)^{5}$ has the general characteristics of a prey item (a large but relatively slow flier), DJ has rarely found it to occur in Coyote scats in Alberta. The low density of this species may explain this, and if so, it can be expected to increase in frequency, after the unprecedented increases in the densities of this species in southern Saskatchewan and southern Alberta in 2002 (from less than one per hectare, to 5 per square meter, at some sites, DJ unpublished data). The large-headed grasshopper (Phoetaliotes nebrascensis) which has a flightless female and occurs later in summer, ${ }^{6}$ appeared in Coyote scats when it was common in the field in 1993 - 1994 at Suffield ${ }^{4}$ and elsewhere (DJ, unpublished data).

Previous studies indicate that insects form a small proportion of the Coyote's diet. For example, Banfield estimated that $1 \%$ of the Coyote diet consisted of insects, based on examination of stomach contents. ${ }^{1}$ In contrast, Adolph Murie, who collected 5,086 Coyote scats in Yellowstone National Park in 1936-1938, found that 711 contained grasshopper remains (an additional 123 scats contained Mormon crickets, Anabrus simplex). He reported that grasshoppers were food items from the time that they became available in summer well into early November, when many fresh droppings had over $90 \%$ grasshopper remains and contained 75 to 100 individuals. ${ }^{9}$ Murie watched Coyotes hunting grasshoppers. In fall, when the insects were inactive, Coyotes appeared to locate them by scent. When the insects were more active earlier in the season, Coyotes hunted them with their paws, or by seizing them with their jaws.
What kind of contribution can grasshoppers make to a Coyote's diet? The average weight of a sample of 10 two-striped males collected in Alberta in 2002 was 0.44 $\mathrm{g}$ live weight $(0.13 \mathrm{~g}$ dry weight), and 10 two-striped females weighed an average of $0.97 \mathrm{~g}$ live weight $(0.34 \mathrm{~g}$ dry weight). Assuming a grasshopper sex ratio of 50:50 (based on field collections of large numbers of grasshoppers, as reported in Johnson 1989b), a typical (for 2002) density of 20 two-striped grasshoppers per square metre represents $4.7 \mathrm{~g}$ dry weight per square metre, or $47 \mathrm{~kg}$ per ha. Since dried grasshopper meal has been determined to be $70 \%$ protein and dried Melanoplus to be $75.3 \%$ crude protein, this represents approximately 33 to $35 \mathrm{~kg}$ of protein per hectare of infested roadside, crop or pasture. ${ }^{8,12}$ Some roadsides, particularly where Smooth Brome (Bromus inermis) is grown, may have densities of up to five times this level, ${ }^{10}$ presenting a high quality and easily accessible food supply to Coyotes and other predators.

1. BANFIELD, A.W.F. 1974. The Mammals of Canada. University of Toronto Press, Toronto.

2. JOHNSON, D.L., 1989a. Spatial autocorrelation, spatial modelling, and improvements in grasshopper survey methodology. The Canadian Entomologist 121: 579-588.

3. JOHNSON, D.L. 1989b. The effects of timing and frequency of application of Nosema locustae (Microspora: Microsporida) on the infection rate and activity of grasshoppers (Orthoptera: Acrididae). Journal of Invertebrate Pathology 54: 353-362.

4. JOHNSON, D.L. 1994. Grasshopper species collected from the Canadian Forces Base Suffield National Wildlife Area in 1994. A report of findings, submitted to the Canadian Wildlife Service. 19 pp. 
5. JOHNSON, D.L. 2001. Band-winged grasshoppers of the Canadian Prairies and the Northern Great Plains. In: H.V. Danks, ed., Arthropods of Canadian Grasslands 7: 5-12; published by the Biological Survey of Canada, Ottawa.

6. JOHNSON, D.L. 2002. Spur-throated grasshoppers of the Canadian Prairies and the Northern Great Plains. In: H.V. Danks, ed., Arthropods of Canadian Grasslands 8: 16-25; published by the Biological Survey of Canada, Ottawa (color).

\section{JOHNSON, D.L. 2003. Slant-faced} grasshoppers of the Canadian Prairies and the Northern Great Plains. In: H.V. Danks, ed. Arthropods of Canadian Grasslands 9 (in press); published by the Biological Survey of Canada, Ottawa.

8. MCHARGUE, J. S. 1917. A study of the proteins of certain insects with respect to their value as food for poultry. J. Agric. Res. 10: 633-637.

9. MURIE, A. 1940. Ecology of the Coyote in the Yellowstone. Fauna of the National Parks of the United States, Series No. 4. United States Government Printing Office, Washington, DC.

10. PFRA (2003). Prairie Farm Rehabilitation Administration, Agriculture and Agri-Food Canada. http://www.agr.gc.ca/pfra/drought/ grasshopper_e.htm

11. SAVAGE, C. 2002. Peril of the Prairie? Canadian Geographic May/June, 2002: 42-50.

12. UECKERT, D. N.; YANG, S. P.; ALBIN, R. C. 1972. Biological value of rangeland grasshoppers as a protein concentrate. Journal of Economic Entomology 65:1286-1288.

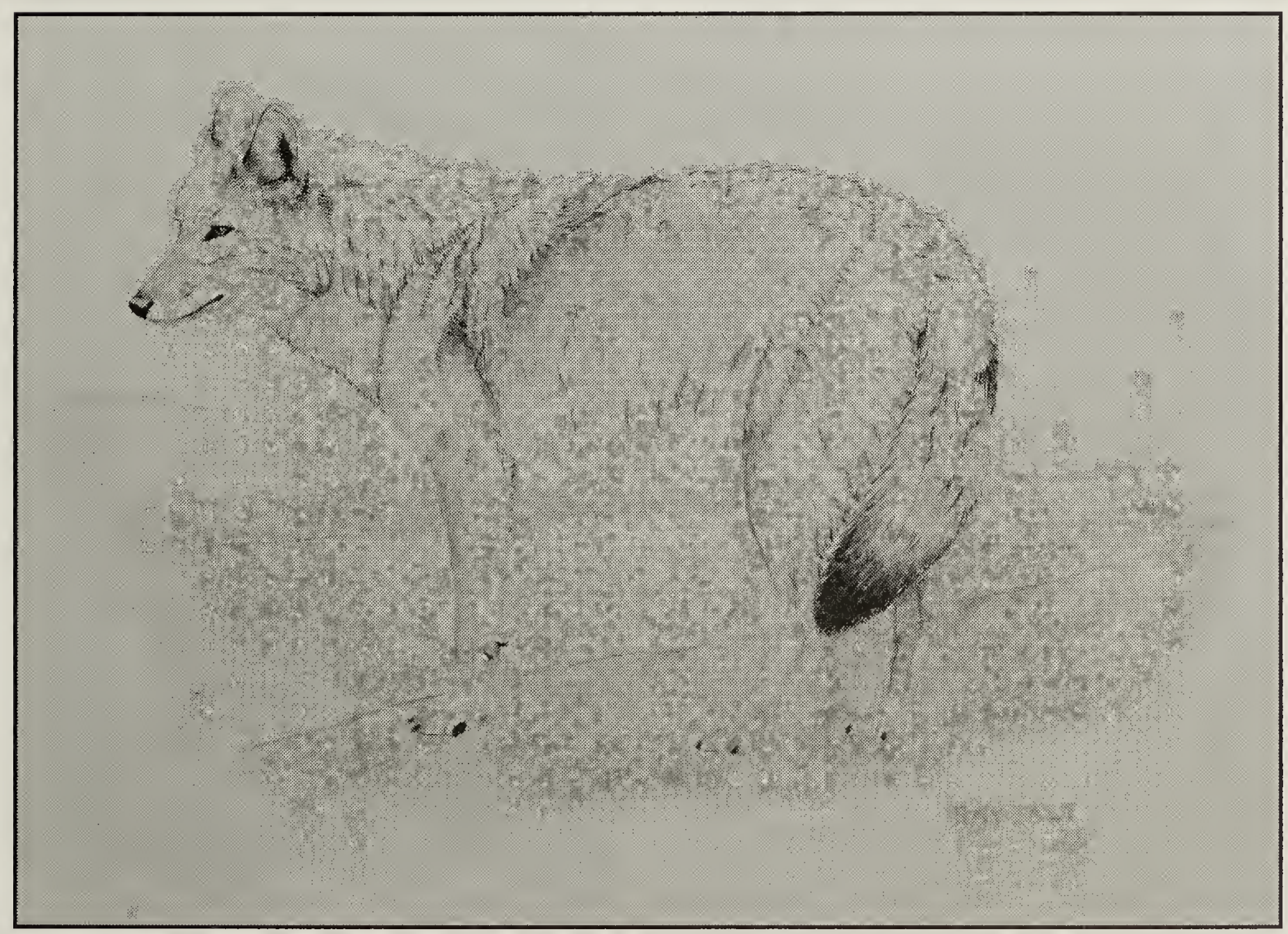

